\title{
Distribution of Congenitally Missing Teeth (Hypodontia) and Its Prevalence in Orthodontic Patients. Study at Princess Basma Teaching Hospital
}

\author{
Dr. Ali Abdul Kareem Abu Ain
}

\begin{abstract}
Study Background and its purpose: congenitally missing teeth (Hypodontia) is considered one of the frequently observed phenomena in the orthodontic clinic. Therefore, this study aimed to determine the prevalence of congenitally missing teeth and its relation to gender in a sample of orthodontics patients at the Princess Basma Teaching Hospital in Irbid from 08/2017 to 08/2018.

Study Sample and its Methodology: The study sample consisted of 2212 patients who visited the orthodontic clinic at the Princess Basma Teaching Hospital in Irbid, aged 9-27 years. The data of the study were collected through clinical and radiological examination of the patients, where the lost permanent teeth were counted. Pearson's chi-squared test ( $\chi 2)$ was used at 5\% significance level to investigate the significance of differences between males and females.

Results: The number of lost permanent teeth was 810 in 196 patients, which is $8.86 \%$ of the individuals of the population of the study. The study showed that (except the third molars), the maxillary lateral incisor is the most lost by $36 \%$. Then, the mandibular second premolars with $28 \%$ followed the maxillary second premolars and the mandibular molars by $9 \%$. The first premolars were lost by $6 \%$ then the mandibular second molars by 5\%, while the canines, the maxillary second molars and maxillary central incisor were rarely absent. There was no observation about the absence of the maxillary and mandibular first molars. It was noticed that $88 \%$ of the patients have lost more than one tooth. The arithmetic average of lost teeth in the males (except the third molars) equal 2.16 teeth while it was equal 2.36 for the females which indicates that there is no significant difference according to gender.
\end{abstract}

Recommendations: the percentage of congenitally missing teeth was high especially the mandibular second premolars and the maxillary lateral incisors. The study recommended making panoramic images for the patients before treatment.

\section{Introduction}

The congenital absence of one or more teeth is a relatively common anomaly in human populations. Nonsyndromic or familial Hypodontia occurs as an isolated trait, while Syndromic Hypodontia occurs with accompanying genetic disease. The term Hypodontia is generally used to describe congenital tooth absence; more specifically Hypodontia refers to a lack of one to six teeth (excluding third molars), also Oligodontia refers to a lack of more than six teeth (excluding third molars); and Anodontia refer to congenital absence of all teeth; deciduous and permanent. Hypodontia is a highly prevalent and costly dental anomaly. Besides an unfavorable appearance, patients with missing teeth may suffer from malocclusion, periodontal damage, insufficient alveolar bone growth, reduced chewing ability, inarticulate pronunciation and other problems. Treatment might be usually expensive and multidisciplinary. Most of these cases could be detected early only through both clinical and radiological examination, as well as the investigation of the reasons for absence to eliminate other causes such as trauma and legions caused by necrosis, prophylaxis for orthodontic reasons. Early detection of the absence of teeth contributes to the patient's ability to provide therapeutic, compensatory and orthodontic solutions through the planning of comprehensive multidisciplinary treatment. The absence of multiple teeth is accompanied by special structural characteristics.

The study sample and its methodology: the study sample consisted of 2212 patients who visited the orthodontic clinic at the Princess Basma Teaching Hospital in Irbid, aged 9-27 years. The sample comprised (1328 females) and (884 males). Patients had a panoramic radiology, and the clinical and radiological data of them were thoroughly investigated. 


\section{Statistical Study}

SPSS 17.0 were used to statistically analyze the data to conclude the results. Pearson's chi-squared test $(\chi 2)$ was used at 5\% significance level to investigate the significance of differences between males and females.

\section{Results}

Description of Study Sample: the study included 2212 orthodontic clinic patients, females formed $60 \%$ of the sample (1328 females) while the males formed $40 \%$ of the sample ( 884 males). The number of patients who have at least one missing tooth (excluding third molars) equal 196 patients $(8.86 \%)$. The cases were distributed as follows: 62 males $(31.6 \%)$ and 134 female $(68.4 \%)$. It was found that 810 teeth were missing, where 360 of them of the third molars and the rest 450 were distributed as shown in tables (1) and (2).

Table (1) Number of missing teeth of the study sample according to the type of the tooth and its location

\begin{tabular}{|l|c|c|c|c|c|c|c|c|c|}
\hline $\begin{array}{l}\text { Type of } \\
\text { tooth }\end{array}$ & $\begin{array}{c}\text { Third } \\
\text { molar }\end{array}$ & $\begin{array}{c}\text { Second } \\
\text { molar }\end{array}$ & $\begin{array}{c}\text { First } \\
\text { molar }\end{array}$ & $\begin{array}{c}\text { Second } \\
\text { premolar }\end{array}$ & $\begin{array}{c}\text { First } \\
\text { premolar }\end{array}$ & Canine & $\begin{array}{c}\text { Lateral } \\
\text { incisor }\end{array}$ & $\begin{array}{c}\text { central } \\
\text { incisor }\end{array}$ & Sum \\
\hline Upper teeth & 202 & 12 & 0 & 40 & 26 & 6 & 160 & 8 & 454 \\
\hline Lower teeth & 158 & 22 & 0 & 128 & 2 & 2 & 18 & 42 & 356 \\
\hline
\end{tabular}

Table (2) The percentage of missing teeth

\begin{tabular}{|l|c|c|c|c|c|c|c|c|c|}
\hline $\begin{array}{l}\text { Type of } \\
\text { tooth }\end{array}$ & $\begin{array}{c}\text { Third } \\
\text { molar }\end{array}$ & $\begin{array}{c}\text { Second } \\
\text { molar }\end{array}$ & $\begin{array}{c}\text { First } \\
\text { molar }\end{array}$ & $\begin{array}{c}\text { Second } \\
\text { premolar }\end{array}$ & $\begin{array}{c}\text { First } \\
\text { premolar }\end{array}$ & Canine & $\begin{array}{c}\text { Lateral } \\
\text { incisor }\end{array}$ & $\begin{array}{c}\text { Central } \\
\text { incisor }\end{array}$ & Sum \\
\hline Upper teeth & 0.25 & 0.01 & 0.00 & 0.05 & 0.03 & 0.01 & 0.20 & 0.01 & 0.56 \\
\hline Lower teeth & 0.20 & 0.03 & 0.00 & 0.16 & 0.00 & 0.00 & 0.02 & 0.05 & 0.44 \\
\hline
\end{tabular}

The mostly missed tooth is the maxillary third molar accounted 202 with $25 \%$ followed by lateral incisor accounted 160 with $20 \%$ then the mandibular third molar accounted 158 with $20 \%$. Then comes mandibular Second premolar with 128 in number and $16 \%$ followed by the mandibular central incisor accounted 42 and forming 5\%. Then the maxillary Second premolar accounted 40 with 5\%.

The number of the upper missing teeth equal 254 where the third molar comprised $44 \%$ of them and the lowest

Table (3) The percentage of missing upper teeth

\begin{tabular}{|l|c|c|c|c|c|c|c|c|}
\hline Type of tooth & $\begin{array}{c}\text { Third } \\
\text { molar }\end{array}$ & $\begin{array}{c}\text { Second } \\
\text { molar }\end{array}$ & $\begin{array}{c}\text { First } \\
\text { molar }\end{array}$ & $\begin{array}{c}\text { Second } \\
\text { premolar }\end{array}$ & $\begin{array}{c}\text { First } \\
\text { premolar }\end{array}$ & Canine & $\begin{array}{c}\text { Lateral } \\
\text { incisor }\end{array}$ & $\begin{array}{c}\text { Central } \\
\text { incisor }\end{array}$ \\
\hline Upper teeth & 0.44 & 0.03 & 0.00 & 0.09 & 0.06 & 0.01 & 0.035 & 0.02 \\
\hline
\end{tabular}

missing teeth was the first molar as shown in table (3).

The number of the lower missing teeth equal 356 teeth where the third molar comprised $44 \%$ of them followed by the second premolar with $36 \%$ and the lowest missing type was the first molar with $0 \%$.

Table (4) The percentage of missing lower teeth

\begin{tabular}{|l|c|c|c|c|c|c|c|c|}
\hline Type of tooth & $\begin{array}{c}\text { Third } \\
\text { molar }\end{array}$ & $\begin{array}{c}\text { Second } \\
\text { molar }\end{array}$ & $\begin{array}{c}\text { First } \\
\text { molar }\end{array}$ & $\begin{array}{c}\text { Second } \\
\text { premolar }\end{array}$ & $\begin{array}{c}\text { First } \\
\text { premolar }\end{array}$ & Canine & $\begin{array}{c}\text { Lateral } \\
\text { incisor }\end{array}$ & $\begin{array}{c}\text { Central } \\
\text { incisor }\end{array}$ \\
\hline Lower teeth & 0.44 & 0.06 & 0.00 & 0.36 & 0.01 & 0.01 & 0.05 & 0.07 \\
\hline
\end{tabular}

Table (5) Distribution of patients according to the number of missing teeth

\begin{tabular}{|l|c|c|c|c|c|c|c|c|c|c|}
\hline $\begin{array}{l}\text { No. of Missing } \\
\text { Teeth }\end{array}$ & 2 & 4 & 6 & 8 & 10 & 12 & 14 & 16 & $\begin{array}{c}\text { More } \\
\text { than } 16\end{array}$ & Sum \\
\hline No. of Patients & 44 & 32 & 22 & 18 & 22 & 24 & 12 & 8 & 14 & 196 \\
\hline
\end{tabular}

When calculating the arithmetic average and the standard deviation of missing teeth including the third molar it was found that the mean of the missing teeth equal 4.13 teeth with a standard deviation of 3.04.

The mean of the missing teeth equal 3.58 teeth with a standard deviation of 3.24 for the males group compared to 4.39 mean and 2.93 standard deviation for the females group. 
Table (6) Distribution of patients according to the number of the missing teeth and gender including the third molar as a percentage

\begin{tabular}{|c|c|c|c|}
\hline No. of missing teeth & Male (\%) & Female (\%) & Sum \\
\hline 1 & $8(26)$ & $14(21)$ & 22 \\
\hline 2 & $7(23)$ & $9(13)$ & 16 \\
\hline 3 & $5(16)$ & $6(9)$ & 11 \\
\hline 4 & $3(10)$ & $6(9)$ & 9 \\
\hline 5 & $1(3)$ & $10(15)$ & 11 \\
\hline 6 or more & $7(23)$ & $22(33)$ & 29 \\
\hline Sum & 31 & 67 & 98 \\
\hline
\end{tabular}

When comparing the males group with the females group according to the number of missing teeth using Pearson's chi-squared test $(\chi 2)$ it was found that $p=0.343$ at $\alpha=0.05$ significance level. So one fails to reject the null hypothesis, which states that there is no difference in number of missing teeth according gender variable.

Chi-Square Tests

\begin{tabular}{|l|c|c|c|}
\hline & Value & Df & Asymp.Sip. (2-sidedP) \\
\hline Pearson Chi-Square & $5.636^{*}$ & 5 & 0.343 \\
\hline Likelihood Ratio & 6.174 & 5 & 0.290 \\
\hline Linear-by-Linear Association & 2.810 & 1 & 0.049 \\
\hline N of Valid Cases & 98 & & \\
\hline$* 3$ cells (25.0\%) have expected count less than 5. The minimum expected count in 2.85. \\
\hline
\end{tabular}

When calculating the arithmetic average and the standard deviation of the number of the missing teeth for a sample of patient both males and females with considering the third molars, it was found that the arithmetic average equals 2.30 teeth with 1.94 standard deviation.

For the males group, it was found that the arithmetic average equals 2.16 teeth with 2.22 standard deviation while for the females group; it was found that the arithmetic average equals 2.36 teeth with 1.18 standard deviation.

The sample was distributed to two groups (males and females) and is divided according to the number of the missing teeth excluding the third molars as shown in table (7).

Table (7) Distribution of patients according to number of missing teeth and gender excluding third molars as a percentage

\begin{tabular}{|c|c|c|c|}
\hline Number of missing teeth & Males (\%) & Females (\%) & Sum \\
\hline 1 & $13(41.9)$ & $(41.8) 28$ & 41 \\
\hline 2 & $13(41.9)$ & $(29.2) 20$ & 33 \\
\hline 3 & $2(6.5)$ & $(7.5) 5$ & 7 \\
\hline 4 & $1(3.2)$ & $(9) 6$ & 4 \\
\hline 5 & $1(3.2)$ & $(4.5) 3$ & 6 \\
\hline 6 or more & $1(3.2)$ & $(7.5) 5$ & 98 \\
\hline Sum & 31 & 67 & 7 \\
\hline
\end{tabular}

When comparing the males group with the females group according to the number of missing teeth excluding third molars using Pearson's chi-squared test $(\chi 2)$ it was found that $\mathrm{p}=0.343$ at $\alpha=0.05$ significance level. So one fails to reject the null hypothesis, which states that there is no difference in number of missing teeth according gender variable. 


\section{Chi-Squared Test}

\begin{tabular}{|l|c|c|c|}
\hline & Value & Df & Asymp. Sip. (2-sided) \\
\hline Pearson Chi-Square & $2.626^{*}$ & 5 & 0.757 \\
\hline Likelihood Ratio & 2.822 & 5 & 0.727 \\
\hline Linear-by-Linear Association & 1.111 & 1 & 0.292 \\
\hline N of Valid cases & 98 & & \\
\hline$* 8$ cells $(66,7 \%)$ have expected count less than 5. The minimum expected count is 1.27. \\
\hline
\end{tabular}

When excluding third molars from the sample of missing teeth, the number of missing teeth was 225 teeth. The number of upper missing teeth was $126(56 \%)$ while the number of lower missing teeth was $99(44 \%)$. The most missed teeth were as follows: for Maxilla was lateral incisor with 80 teeth forming $64 \%$ while for mandible it was the second lower premolar with 64 teeth forming 65\%, see tables (8) and (9).

Table (8) Number of missing teeth in the Maxilla and their percentage

\begin{tabular}{|l|c|c|c|c|c|c|c|c|}
\hline Type of tooth & $\begin{array}{c}\text { Second } \\
\text { molar }\end{array}$ & $\begin{array}{c}\text { First } \\
\text { molar }\end{array}$ & $\begin{array}{c}\text { Second } \\
\text { premolar }\end{array}$ & $\begin{array}{c}\text { First } \\
\text { premolar }\end{array}$ & Canine & $\begin{array}{c}\text { Later } \\
\text { incisor }\end{array}$ & $\begin{array}{c}\text { Central } \\
\text { incisor }\end{array}$ & Sum \\
\hline Upper teeth & 6 & 0 & 20 & 13 & 3 & 80 & 4 & 126 \\
\hline Percentage & $5 \%$ & $0 \%$ & $16 \%$ & $10 \%$ & $2 \%$ & $64 \%$ & $3 \%$ & $100 \%$ \\
\hline
\end{tabular}

Table (9) Number of missing teeth in the mandible and their percentage

\begin{tabular}{|l|c|c|c|c|c|c|c|c|}
\hline Type of tooth & $\begin{array}{c}\text { Second } \\
\text { molar }\end{array}$ & $\begin{array}{c}\text { First } \\
\text { molar }\end{array}$ & $\begin{array}{c}\text { Second } \\
\text { premolar }\end{array}$ & $\begin{array}{c}\text { First } \\
\text { premolar }\end{array}$ & Canine & $\begin{array}{c}\text { Lateral } \\
\text { incisor }\end{array}$ & $\begin{array}{c}\text { Central } \\
\text { incisor }\end{array}$ & Sum \\
\hline Lower teeth & 11 & 0 & 64 & 1 & 2 & 9 & 12 & 99 \\
\hline Percentage & $11 \%$ & $0 \%$ & $65 \%$ & $1 \%$ & $2 \%$ & $9 \%$ & $12 \%$ & $100 \%$ \\
\hline
\end{tabular}

In general, when excluding third premolars, the most missing in descending order was as follows: maxillary lateral incisor with $36 \%$, mandibular second premolars with $28 \%$, maxillary second molars $3 \%$, and the lower incisors with $9 \%$, maxillary first premolars with $6 \%$, then mandibular second molars with $5 \%$. It is noticed that Canines, maxillary second molars and maxillary central incisors were rarely missed and that first maxillary and mandibular molars were never missed.

Table (10) Number of missing teeth in general for both jaws excluding third molars in percentage

\begin{tabular}{|l|c|c|c|c|c|c|c|c|}
\hline Type of tooth & $\begin{array}{c}\text { Second } \\
\text { molar }\end{array}$ & $\begin{array}{c}\text { First } \\
\text { molar }\end{array}$ & $\begin{array}{c}\text { Second } \\
\text { premolar }\end{array}$ & $\begin{array}{c}\text { First } \\
\text { premolar }\end{array}$ & Canine & $\begin{array}{c}\text { Lateral } \\
\text { Incisor }\end{array}$ & $\begin{array}{c}\text { central } \\
\text { incisor }\end{array}$ & Sum \\
\hline Upper teeth & $3 \%$ & $0 \%$ & $9 \%$ & $6 \%$ & $1 \%$ & $36 \%$ & $2 \%$ & $56 \%$ \\
\hline Lower teeth & $5 \%$ & $0 \%$ & $28 \%$ & $0 \%$ & $1 \%$ & $4 \%$ & $5 \%$ & $44 \%$ \\
\hline
\end{tabular}

\section{Results}

This study was designed to identify the distribution of congenitally missing teeth (Hypodontia) and its relationship with gender for a sample of 2212 of Orthodontic clinic patients at the Princess Basma Teaching Hospital in Irbid. The history of each patient was studied to exclude the cases for which the reason of missing is attributed to reason such as trauma and tooth decay due to injury or inflammation of the supporting tissue or extraction for Orthodontic reasons, also cases of syndromes and birth defects were excluded.

This study excluded the third molar from the percentage of congenitally missing teeth as they have many anomalies and occupy the highest percentage when included. In the current study, the percentage of missing teeth except the third molars was $8.86 \%$, which a relatively high percentage compared with the study of Sisman. It is also less than what is mentioned by Fekonja who found in his study that the percentage of missing teeth is higher than the rest of the studies, as well as the study of Gabris.

However, other studies such as Goren, Salama, Abdel-Majid, Amran, Bashira, Khader, SILVA, and Sarhan had a relatively low percentage of missing teeth due to variance in study samples of the different studies. In this study, the percentage of the missing of the maxillary third molar was the highest $25 \%$. 
The percentage of missing maxillary lateral Incisor was equal to the percentage of missing of mandibular third molars $20 \%$ followed by the mandibular second premolars $16 \%$. Missing maxillary second premolars percentage was equal to missing lower Incisor percentage of 5\% while missing maxillary first premolars percentage was equal to mandibular second molars $3 \%$. While the maxillary central incisor was the lowest percentage $1 \%$. It has been shown that there is no evidence for missing upper or lower premolar due to congenitally reasons in case of the sample of the study. This is consistent with most of the previous studies. Certon said that the first premolars are most stable followed by the upper internal incisors. In the current study, the upper incisors ranked first followed by the second lower molars, excluding missing third premolars. Both types of teeth occupied the first rank with relatively equal percentages (64 and 65\%) if the absence of upper incisor in the upper jaw and the missing of lower molars in the lower jaw were considered excluding the third premolars. The percentage of patients with 6 or more missing teeth was $29 \%$ of patients who suffer from congenitally missing teeth (Hypodontia), which is high percentage. This indicates the importance of conducting panoramic radiographs for the discovery of any permanent missing tooth. 88 of the patients have no more than one missing tooth. Therefore, the results of the current study disagreed in this side with Sisman study conducted in Turkey as most patients had only one or two missing teeth and rarely three or more. The study disagreed with Sarhan's clinical study in 2008, with $24.1 \%$ missing teeth.

\section{Recommendations}

Within the limits of this study, the percentage of congenitally missing teeth is particularly high, especially mandibular second premolars and the maxillary lateral incisors. Therefore, the routine panoramic images are recommended for patients before treatment, especially if it is clinically discovered that one of the permanent teeth are missing.

\section{References}

Sisman Y, Uysal T, Gelgor I E. Hypodontia .Does the prevalence and distribution pattern differ in orthodontic patients? Eur J Dent.2007;1:167-73.

Gabris K , Tarjan I, Csiki P, Korad F, SzadeczkyB, Rozsa N. Prevalence of congenital hypodontia in the permanent dentition and its treatment. FogorvSz. 2001;94:137-40.

Goren S, Tsoizner R , Dinbar A, Levin L, Breznik N. Prevalence of congenitally missing teeth. RefuatHapehVehashinayim. 2005;22:49-53,87.

Fekonja A. Hypodontia in orthodontically treated children. Eur J Orthod.2005;27:457-60.

Salama F S, Abdel-Mejid F Y. Hypodontia of Primary and Permanent teeth in a sample of Saudi children. Egypt Dent J.1994;40:625-32.

Creton M A,Cune M S,Verhoeven W, Meijer G J. Patterns of missing teeth in a population of oligodontia patients. Int J Prosthodont. 2007;20:409-13.

Al-Emran S. Prevalence of hypodontia and developmental malformation of Permanent teeth in Saudia Arabian. Br J Orthod.1990;17:115-8.

Silva Moza R. Radiographic assessment of congenitally missing teeth in orthodontic patients. Int J Paediatr Dent. 2003;13:112-6.

Albashaireh Z S, Khader Y S. The prevalence and pattern of hypodontia of the permanent teeth and crown size and shape deformity affecting upper lateral incisors in a sample of Jordanian dental patients. Community Dent Health. 2006;23:239-43.

Sarhan R., Study of the prevalence of dental developmental disorders in schoolchildren aged 12-4 years in Damascus. Master Thesis, Faculty of Dentistry, Damascus University, 2008: -72 81. 